\title{
Ultrastructural study of spontaneous orocutaneous papillomas of brown bullheads Ictalurus nebulosus
}

\author{
Frederique M. Poulet*, Jan M. Spitsbergen
}

Department of Avian and Aquatic Animal Medicine, New York State College of Veterinary Medicine, Cornell University, Ithaca, New York 14853, USA

\begin{abstract}
Eight spontaneous orocutaneous papillomas of adult, wild-caught brown bullheads Ictalurus nebulosus and 4 anatomically matching control tissue samples were examined by electron microscopy. Ultrastructural characteristics of normal and neoplastic Malpighian epithelial cells were compared and neoplastic cells were described. Normal Malpighian epithelial cells of brown bullheads were similar to those of other teleosts. Euchromatic nucleus, abundant nuclear pores and numerous ribosomes suggested elevated protein synthetic activity in both normal and neoplastic Malpighian cells. Three morphological alterations were consistently present in neoplastic cells: loss of zonal cytoplasmic distribution of organelles, well-developed vesicular system and disorganization of bundles of intermediate filaments (cytokeratin, presumably) with frequent whorl formation. These changes suggest a high membrane-generating activity and imperfect differentiation in these cells, which would be compatible with their neoplastic nature. There were no other significant morphological differences between normal and neoplastic Malpighian epithelial cells. No virus particles were detected in the 8 papillomas examined.
\end{abstract}

KEY WORDS: Brown bullhead ICtalurus nebulosus - Mucosa - Papilloma - Skin - Ultrastructure

\section{INTRODUCTION}

Orocutaneous papillomas and carcinomas are the most common spontaneous neoplasms of wild brown bullheads Ictalurus nebulosus throughout North America (Poulet et al. 1994). This neoplastic condition is manifested in adult brown bullheads usually as multiple or, less frequently, solitary papillomatous masses arising from the oral and/or cutaneous epithelia. Benign papillomas can apparently progress to locally invasive carcinomas.

Although orocutaneous neoplasms of brown bullheads have been recognized since the 1930s, their etiology remains unresolved. Correlations between tumor occurrence and chemical environmental conta-

\footnotetext{
- Present address: Department of Veterinary Pathobiology College of Veterinary Medicine, University of Illinois, 2001 South Lincoln Avenue, Urbana, Illinois 61801, USA.

E-mail: poulet@ux1.cso.uiuc.edu
}

minants are unclear (Bowser et al. 1991). Electron microscopic examination of one specimen revealed intracytoplasmic virus-like particles in the epidermal cells, suggesting that those neoplasms might have an infectious etiology (Edwards \& Samsonoff 1977). The presence of viral particles in the tumor cells, however, was not corroborated by other investigators (Bowser et al. 1991). Attempts to reproduce the lesions under laboratory conditions using cell-free, filtered tumor tissue homogenate or live neoplastic cells were unsuccessful (Poulet et al. 1993).

The macroscopic and histological features of the orocutaneous papillomas and carcinomas of brown bullheads have been reported (Bowser et al. 1991, Poulet et al. 1994). The present ultrastructural study analyzes and compares the normal orocutaneous epithelium and that of orocutaneous tumors from brown bullheads and describes the morphological alterations of the Malpighian epithelial cells in the orocutaneous tumors 


\section{MATERIALS AND METHODS}

Eight tumor tissue samples (Cases 5 to 12) and 4 matching anatomic control tissue samples (Cases 1 to 4) were excised from individual adult brown bullheads anesthetized with methane tricaine sulfonate (MS 222; Sandoz Pharmaceuticals, East Hannover, NJ, USA). All fish were obtained in May/June from the following bodies of water in New York State, USA: 4 fish (Cases 5 to 8) were collected from Silver Stream Reservoir (Orange County), 5 (Cases 4, 9 to 12) from Delta Lake (Oneida County) and 3 control brown bullheads (Cases 1 to 3 ) were caught in a private pond at Marathon (Cortland County). Representative sections were processed separately for routine histological examination to confirm the diagynosis of papilloma. The neoplasms were finely minced into $1 \mathrm{~mm}^{3}$ sections and fixed in $2.5 \%$ glutaraldehyde in $0.1 \mathrm{M}$ cacodylate buffer ( $\mathrm{pH} 7.4$ ) for 24 to $48 \mathrm{~h}$ at $4^{\circ} \mathrm{C}$. After rinsing, the tissues were postfixed in $1 \%$ osmium tetroxide for $1 \mathrm{~h}$, then serially dehydrated through a graded ethanol and propylene oxide series, and finally infiltrated and embedded in a mixture of Araldite and Epon. Thick sections, cut at $1 \mu \mathrm{m}$ with a glass knife and stained with toluidine blue, were screened for orientation and presence of lesion. Thin sections were obtained with a diamond knife, stained with $2 \%$ uranyl acetate and lead citrate and examined under a Zeiss TEM 902 electron microscope.

\section{RESULTS}

Fish epidermis is subdivided into a basal, an intermediate and a superficial layer for practical descriptive reasons. In most piscine species there is no gradual differentiation or keratinization of the chief epidermal cell, the Malpighian epithelial cell, throughout those 3 layers (Henrikson \& Matoltsy 1968a, Merrilees 1974). In the present study the Malpighian epithelial cells, also referred to as filament-containing cells, were studied in the basal, intermediate and superficial layers for all the normal control cases and in the corresponding zones for the tumors. The ultrastructure of the normal epidermal cells, including Malpighian epithelial cells and other cell types, from the control brown bullheads Cases 1 to 4 did not differ appreciably from that of similar cells in other teleosts. The less frequently encountered cell types comprised goblet cells, macrophages, lymphocytes and granule-containing cells in the epidermis and melanophores and iridophores in the dermis. All those cell types were very similar across different teleost species (Henrikson \& Matoltsy 1968a, b, Merrilees 1974).
Most ultrastructural features observed in normal Malpighian epithelial cells were preserved in neoplastic ones. The basement membrane supporting the basal epithelial cells was wavy and uninterrupted. Fig. 1 shows an overall view of the Malpighian epithelial cells in the central part of a papilloma (Case 11), an area that corresponded to the intermediate layer of the epidermis. The Malpighian cells of the basal and intermediate layers were closely apposed, irregularly polygonal cells. They sent abundant and usually slender cytoplasmic processes of variable length. Those processes interdigitated with neighboring epithelial cells in a complex network of tortuous folds. The lateral plasma membranes of adjacent cells and, occasionally, the cell processes were linked by several, often long, desmosomes. Solitary desmosomes viere less fíequently observed. In one normal specimen (Case 4) and one orocutaneous papilloma (Case 10), isolated intracytoplasmic desmosomes were visualized in epithelial cells. Intracytoplasmic desmosomal structures were characterized by recognizable dense plaques and converging intermediate filaments. No intermediate line, however, was discernible in the intracytoplasmic desmosomes. The nucleus-to-cytoplasm ratio of neo-

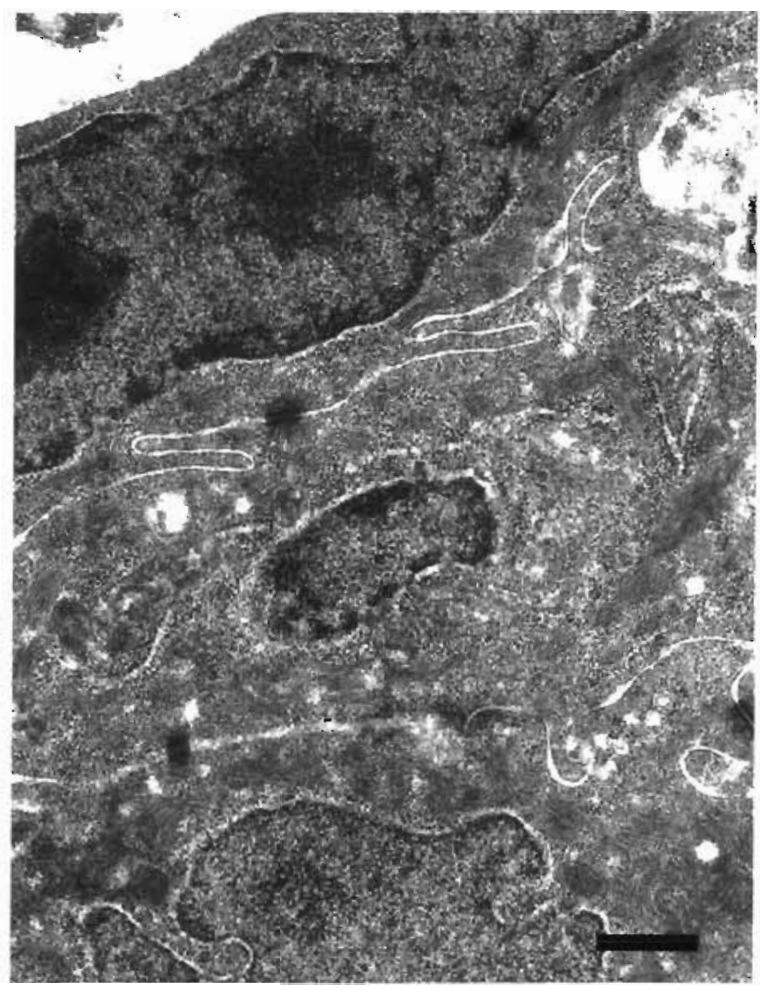

Fig. 1. Ictalurus nebulosus. Transmission electron micrograph. Orocutaneous papilloma of brown bullhead Case 11 Three closely apposed Malpighian epithelial cells with interdigitating cytoplasmic processes are shown. Solitary desmosomes connect their plasma membranes. Uranyl acetate and lead citrate. Scale bar $=0.64 \mu \mathrm{m}$ 
plastic Malpighian epithelial cells was comparable to that of normal cells. The cytoplasm of both normal and neoplastic cells was relatively abundant and of moderate electron density. The distribution of cytoplasmic elements was typically zonal in normal Malpighian epithelial cells. The organelles were mostly located in the perinuclear area, while the peripheral cytoplasmic region contained abundant tonofilaments. The nucleus was centrally located, appeared ovoid and had highly lobulated contours and occasional deep invaginations, which, when transected, created intranuclear pseudoinclusions of perinuclear cytoplasm. The nucleus contained 1 or 2 prominent, central, compact nucleoli with poorly distinct nucleolonema. The nucleoplasm consisted predominantly of low electron-dense euchromatin with small aggregates of heterochomatin that abutted the nuclear membrane, a few dispersed chromatin centers and minimal to moderate amounts of nucleolus-associated heterochromatin. Numerous nuclear pores were visible on tangential sections.

In both normal and neoplastic Malpighian epithelial cells the Golgi complex was constituted by stacks of approximately 3 to 5 flattened saccules with terminal small dilatations. The rough endoplasmic reticulum consisted of solitary or loosely arranged groups of narrow cisternae. A few cisternae exhibited rare vesicular dilatations that contained minute amount of flocculent, electron-lucent material. Scant amounts of ramifying tubulovesicular smooth endoplasmic reticulum were visible in rare cases. In contrast, ribosomes were particularly abundant. They formed rosette-like or curvilinear configurations of polyribosomes or appeared as free elements in the cytoplasm. Moderate numbers of elongated, usually thin, mitochondria were present. These mitochondria were endowed with lamellar, exceptionally tubulovesicular, cristae and contained a few dense intramatricial granules. In rare cells, microtubules were apparent as juxtanuclear groups of slightly undulating hollow cylinders approximately $24 \mathrm{~nm}$ in diameter. In the submembranous cytoplasmic region, small numbers of monomorphic, variably sized, rounded, single membrane-bound granules with a moderately dense homogeneous content represented presumably primary lysosomes. Heterolysosomes were rare.

The epithelial cells of the outermost layer were horizontally flattened and parallel to the epidermis. They desquamated progressively, undergoing gradual degeneration as part of that process. The degenerative changes ranged from early cisternal and mitochondrial vacuolation to cytoplasmic disorganization and progressed to necrosis and complete disintegration. Sparse, small, blunt microvilli protruded from the apical surface of the superficial epithelial cells. These microvilli were supported on a subplasmalemmal terminal web of fine filaments (probably actin). The cell surface was overlaid by an almost imperceptible fuzzy cell coat.

Within the papillomas (Cases 5 to 12) changes were observed in the ultrastructure of the neoplastic Malpighian epithelial cells. Specifically, 3 major morphological alterations occurred consistently in the tumor cells. First, the overall distribution of cytoplasmic elements, namely perinuclear organelles and peripheral intermediate filaments, was disrupted. The orderly zonal arrangement of normal cells was less distinct in some neoplastic cells and even occasionally effaced in others. The intermediate filaments (cytokeratin, presumably) of neoplastic Malpighian epithelial cells did not form regular bundles along the periphery of the cytoplasm but were distributed haphazardly and ran throughout the cytoplasm and among organelles, displacing some organelles to the cell periphery. In neoplastic cells, intermediate filaments were in short, undulating, loosely arranged groups with occasional focal densities (Case 12) and, characteristically, formed innumerable separate small whorls. Those whorls constituted the second ultrastrutural change in neoplastic cells. They frequently encircled groups of 10 or fewer ribosomes (Fig. 2).

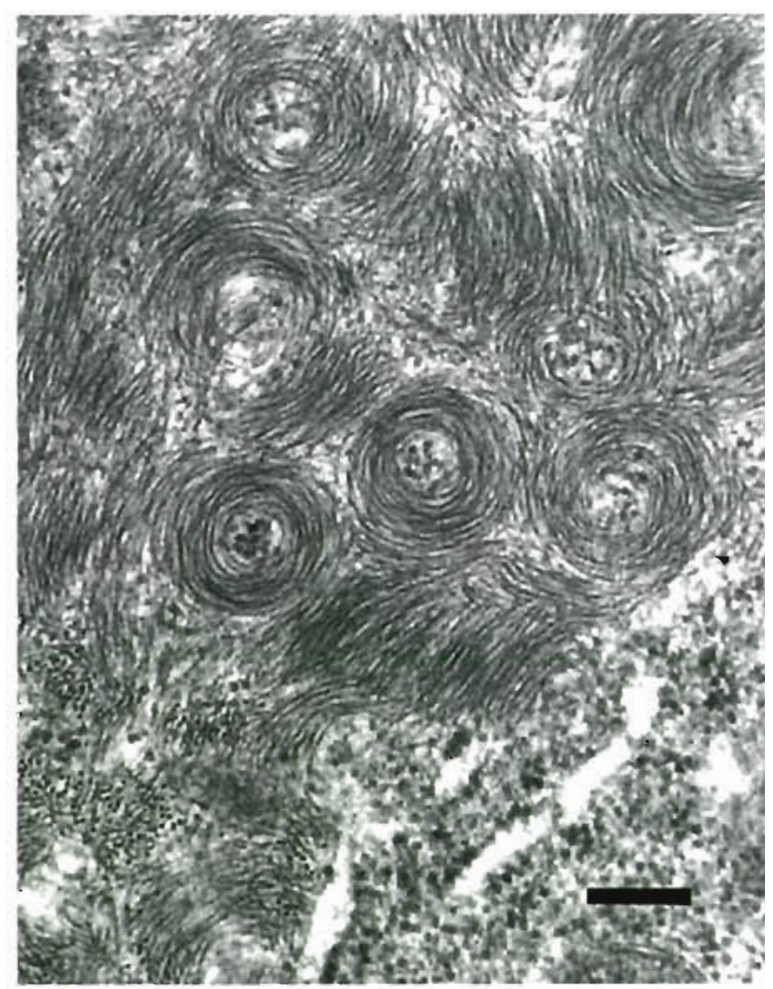

Fig. 2. Ictalurus nebulosus. Transmission electron micrograph. Orocutaneous papilloma of brown bullhead Case 10. Numerous small whorls of intermediate filaments encircle occasionally groups of a few ribosomes. Uranyl acetate and lead citrate. Scale bar $=0.18 \mu \mathrm{m}$ 
The third ultrastructural difference between normal and neoplastic Malpighian epithelial cells consisted of a well-developed vesicular system in neoplastic cells Indeed, the various components of the vesicular system were strikingly abundant in neoplastic cells, a feature which suggested intensive vesicle-generating activity in those cells. The peripheral cytoplasm contained significant numbers of coated pits and submembranous coated vesicles. Occasional prominent multivesicular bodies (Fig. 3) were present. Many variably sized vesicles around the rough endoplasmic reticulum were partially or totally covered by attached ribosomes. Those vesicles emerged from the rough endoplasmic reticulum and gathered around the convex face of the Golgi complex (Figs. 4 \& 5). Numerous single membrane-bound vacuoles, detached from the conrave face of the Golgi complex, formed the trans Golgi network. Those vacuoles had an electron-lucent content. They showed no gradation in size as they migrated toward the cell periphery.

In Case 11, several irregularly ovoid, nonmembranebound, granular, intracytoplasmic inclusions were discerned in the juxtanuclear area of a few epithelial cells. The nature of these granular inclusions remained unknown. There were no other differences between

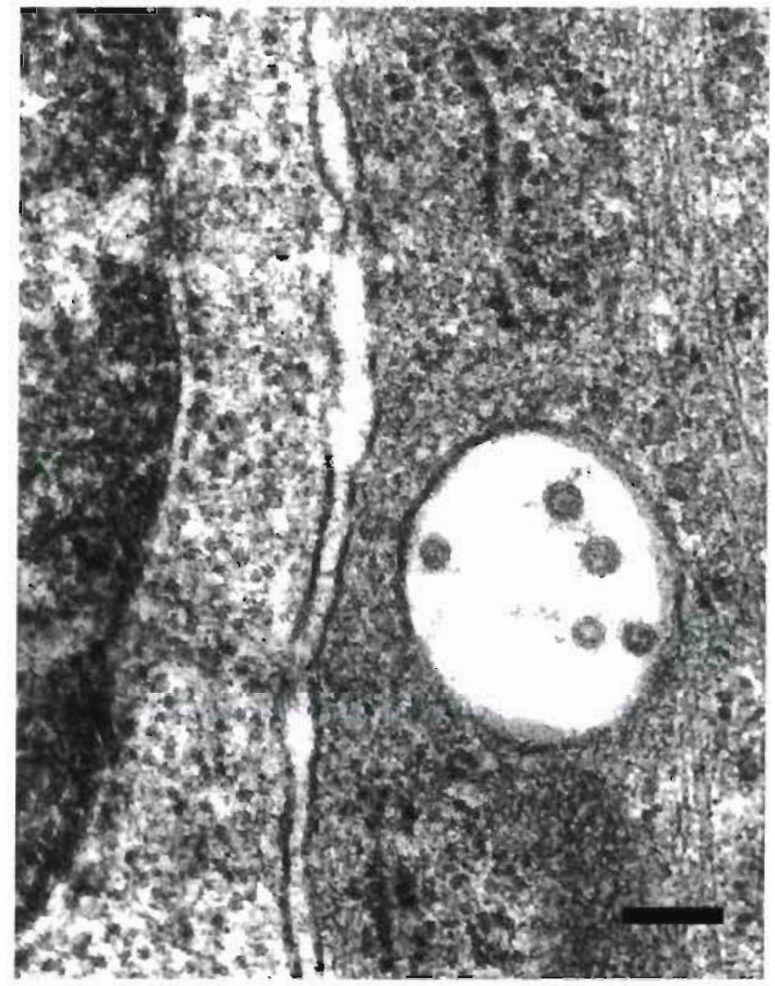

Fig. 3. Ictalurus nebulosus. Transmission electron micrograph. Orocutaneous papilloma of brown bullhead Case 12 . A solitary multivesicular body is present in the cytoplasm. Uranyl acetate and lead citrate. Scale bar $=0.17 \mu \mathrm{m}$

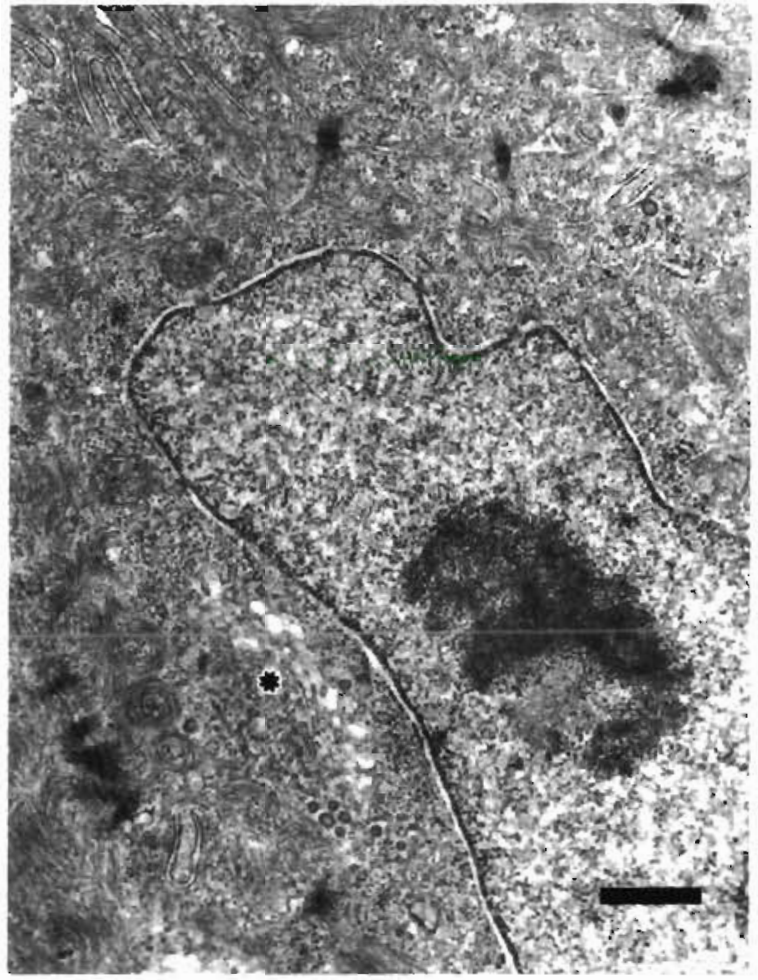

Fig. 4. Ictalurus nebulosus. Transmission electron micrograph. Orocutaneous papilloma of brown bullhead Case 12. Abundant vesicles are around the saccules of the Golgi complex (*). The bundles of intermediate filaments are disorganized and form several small whorls. Uranyl acetate and lead citrate. Scale bar $=0.63 \mu \mathrm{m}$

the ultrastructural features of Malpighian epithelial cells from normal brown bullhead orocutaneous epithelium and papillomas. No viral particles were identified in the 8 tumor specimens examined.

\section{DISCUSSION}

The ultrastructural features of normal Malpighian epithelial cells of brown bullheads corresponded to those described for other teleosts (Henrikson \& Matoltsy 1968a, Merrilees 1974). However, the intracytoplasmic desmosomes, abundant nuclear pores and the few primary lysosomes represented new observations in piscine epithelial cells.

Intracytoplasmic desmosomes were not specific for neoplastic Malpighian epithelial cells as they were also observed in normal cells. These structures are relatively frequent in keratinocytes of mammals under various normal and pathological conditions, but their significance is still speculative (Schenk 1975). Desmosomes might be incorporated into the cytoplasm during mitosis, particularly in cells proliferating actively, or 


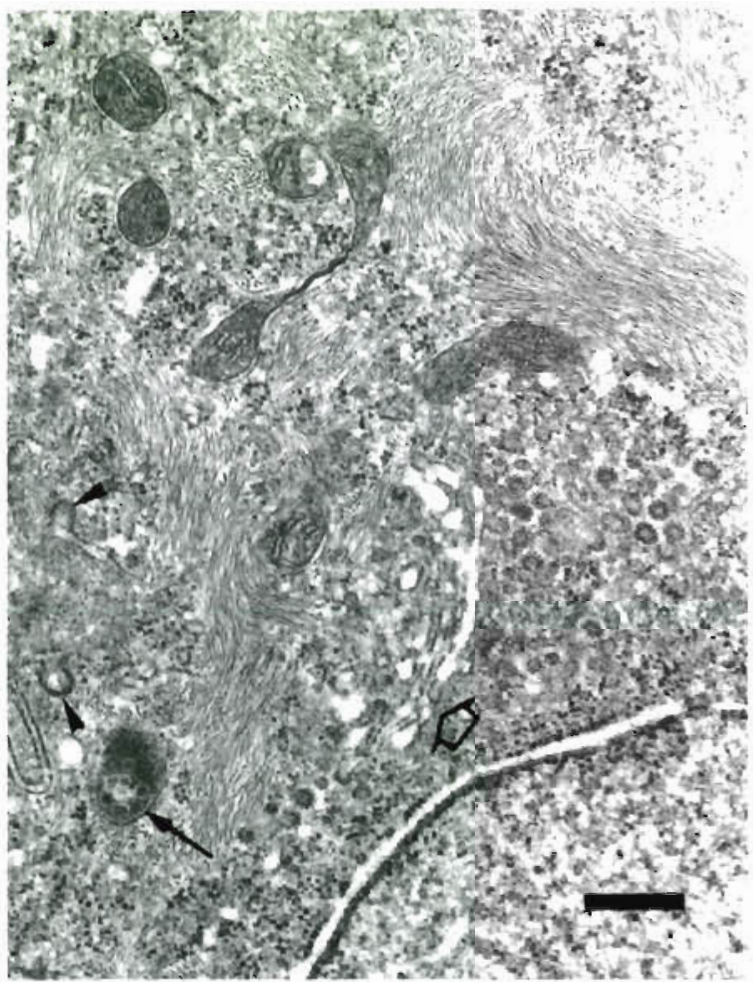

Fig. 5. Ictalurus nebulosus. Transmission electron micrograph Orocutaneous papilloma of brown bullhead Case 12. Numerous vesicles are around the Golgi complex. Open arrow convex face of the Golgi complex. The intermediate filaments course haphazardly among the cytoplasmic organelles. Two coated pits (arrowheads) and one multivesicular body (arrow) are evident in the subplasmalemmal cytoplasm. One mitochondrion is elongated and appears slightly curved. Uranyl acetate and lead citrate. Scale bar $=0.36 \mu \mathrm{m}$

during syncitia formation. Alternatively, their internalization into the cytoplam could result from alterations of the plasma membrane (Schenk 1975). The presence of intracytoplasmic desmosomes in Malpighian epithelial cells of brown bullheads is probably incidental.

The ultrastructural features of orocutaneous papillomas and carcinomas have been described in black bullheads Ictalurus melas exposed to excessively chlorinated water (Grizzle et al. 1984) and in white suckers Castostomus commersoni (Smith et al. 1989). In both cases a similar abundance and distribution of intermediate filaments was observed. The disorganization of the intermediate filament bundles together with loss of zonal cytoplasmic organization and the extensive whorling noted in the neoplastic Malpighian epithelial cells of brown bullheads, however, were not mentioned in white suckers and black bullheads. These changes might be due to the diminished capability of tumor cells to differentiate. In lesions from white suckers the intercellular spaces were widened and there was a profuse infiltration by leukocytes (Smith et al. 1989), which were absent from the brown bullhead orocutaneous papillomas examined in this study

The other most remarkable ultrastructural features of the neoplastic cells from brown bullheads might be compatible with the rapidly growing nature of tumor cells. Intense vesicular traffic has been described as part of an elevated membrane-generating activity in tumor cells (Geuze \& Kramer 1974) In the neoplastic Malpighian epithelial cells this activity might be the cell response to a considerable demand in plasma membrane, which was possibly created by the intricate plasma membrane infoldings. Elaborate regulation of membrane movements is indispensable in order to balance adequately the requirements for membrane expansion and recycling. Fusion of Golgi-derived vacuoles to the cytoplasmic membrane provides additional membrane. In turn, superfluous cytoplasmic membrane is interiorized by endocytosis, as illustrated by coated pits, subplasmalemmal coated vesicles and multivesicular bodies (Geuze \& Kramer 1974). According to one study, multivesicular bodies are thought to arise from endocytotic vesicles by invagination, budding and fission of their limiting membrane, and to participate actively in the quantitative regulation of cytoplasmic membrane (Geuze \& Kramer 1974).

Acknowledgements. Funding for this research was generously provided by the New York State Return a Gift to Wildlife Fund. F.M.P. was supported by a graduate assistantship from NYSCVM Cornell University. This work is part of a dissertation submitted by F.M.P. to the Graduate School Cornell University, Ithaca, in partial fulfillment of the requirements for the degree of Doctor in Philosophy, 1994.

\section{LITERATURE CITED}

Bowser PR, Wolfe MJ, Reimer J, Shane BS (1991) Epizootic papillomas in brown bullheads Ictalurus nebulosus from Silver Stream reservoir. New York. Dis aquat Org 11. $117-127$

Edwards MR, Samsonoff WA (1977) Electron microscopic observations on virus-like particles of a catfish papilloma Proc A. Meet Electron Microsc Soc Am 35:394-395

Geuze JJ, Kramer MF (1974) Function of coated membranes and multivesicular bodies during membrane regulation in stimulated exocrine pancreas cells. Cell Tiss Res 156:1-20

Grizzle JM, Melius P, Strength DR (1984) Papillomas on fish exposed to chlorinated wastewater effluent. J natl Cancer Inst 73:1133-1142

Henrikson RC, Matoltsy AG (1968a) The fine structure of teleost epidermis. I Introduction and filament-containing cells. J Ultrastruct Res 21:194-212

Henrikson RC, Matoltsy AG (1968b) The fine structure of teleost epidermis. III. Club cells and other cell types. J Ultrastruct Res 21:222-232

Merrilees MJ (1974) Epidermal fine structure of the teleost Esox americanus (Esocidae, Salmoniformes). J Ultrastruct Res 47:272-283

Poulet FM, Casey JW, Spitsbergen JM (1993) Studies on the 
transmissibility and etiology of orocutaneous tumors of brown bullheads Ictalurus nebulosus. Dis aquat Org 16 : 97-104

Poulet FM, Wolfe MJ, Spitsbergen JM (1994) Naturally occurring orocutaneous papillomas and carcinomas of brown bullheads (Ictalurus nebulosus) in New York State. Vet Pathol 31:8-18

Responsible Subject Editor: N. Peters, Hamburg, Germany
Schenk P (1975) Desmosomale Strukturen im Cytoplasma normaler und pathologischer Keratinocyten. Arch dermatol Res 253:23-42

Smith IR, Baker KW, Hayes MA, Ferguson HW (1989) Ultrastructure of malpighian and inflammatory cells in epidermal papillomas of white suckers Catostomus commersoni. Dis aquat Org 6:17-26

Manuscript first received: March 28, 1995

Revised version accepted: September 26, 1995 